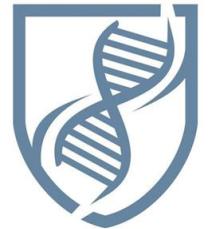

Journal of Bioscience and Applied Research
JBAAR

WWW.JBAAR.ORG

\title{
The radioprotective role of Aphanizomenon flos-aquae (AFA) on testis of adult male albino rats
}

\author{
Fatma Ahmed Eid, Hemmat Mansour Abdelhafez ,Samir Attia Zahkouk1 and Heba Ahmed \\ Mohamed Kandeal \\ Department of Zoology, Faculty of Science, Al-Azhar University, Cairo, Egypt.
}

(Corresponding author email: fatmaeid22@yahoo.com)

\begin{abstract}
This work aimed to study the biochemical,

histopathological and histochemical changes in the testes of male albino rats post exposure to $4 \mathrm{~Gy}$ of gamma radiation and the possible radioprotective role of Aphanizomenon flos-aquae (AFA). Aphanizomenon flos-aquae (AFA) is a blue-green microalgal species which has antioxidant properties. The current experiment was carried out on 48 adult male albino rats (Rattus rattus). Rats were randomly and equally categorized into four groups: 1) Group C: control rats left without treatment; 2) Group R: rats were exposed to 4Gy of gamma-radiation as a single dose; 3 ) Group AFA: rats were terated orally with $94.5 \mathrm{mg} / \mathrm{kg}$ body weight/ day AFA for 3 weeks and 4) Group AFA+R: rats were administrated AFA for a period of one week before and three weeks after irradiation. Results obtained in the present study showed that exposed rats showed a significant increase in MDA in the testes, but decreased testosterone level was detected versus the control.

Many histopathological lesions were observed in the testes tissue such as disturbed spermatogenic layers with vacuolated spermatogenic cells, presence of polynucleated cells, absence of mature sperms, oedema in the interstitial spaces, congested testicular arteries with thickened, dilated and corrugated walls of them, they also contained hemolysed blood cells with highly reduced, atrophied and distorted Leydig cells in the interstitial spaces. Irradiated groups showed highly increased collagen fibres under the testicular capsule, basement membranes, Leydig cells and around the blood vessels with signs of fibrosis in the capsule and some seminiferous tubules. In addition, irradiated group induced a significant increase in amyloid $\beta$ protein, while a significant decrease in PAS+ve materials, total protein and total DNA content was detected. AFA administration ameliorated the damaging effects of testes of radiation exposed rats. Conclusion: according to the results obtained in the current study using Aphanizomenon
\end{abstract}

flos- aquae as a natural agent showed a strong radioprotective role. Key words. Gamma rays, ionizing radiation, Aphanizomenon flos-aquae (AFA), testes, rats.

\section{Introduction}

Due to the progressive development in all areas of science and technology in the world there are a growing number of various sources of radiation. Those include: mobile communications, development of new methods of medical diagnostics, space exploration, creation of nuclear weapons and the development of the nuclear industry and power that led to a serious threat to the environment and human health (Nakamura et al., 2012). Ionizing radiations cause similar damage at the cellular level. Gamma rays and neutrons are more penetrating, causing diffuse damage throughout the body (e.g. radiation sickness, cell's DNA damage, cell death due to damaged DNA, increasing incidence of cancer) rather than burns. The most biological damaging forms of gamma radiation occur in the gamma ray window, between 3 and $10 \mathrm{MeV}$ (Bock, 2008). Whole body gamma-irradiation of animals at the sub lethal and lethal dose levels alters the metabolism of various organs and causes a series of biochemical and physiological disturbances in the different biological tissues (Mohammed et al., 2010). Ibrahim and Ghoneim (2014) reported that radiation induced ROS and free radicals react with the molecules of cell membranes and induce lipid peroxidation products (MDA), which play an important role in the biological damage such as mutagenic and carcinogenic damage. They also demonstrated many histopathological and biochemical changes in the testes tissue, gonadal insufficiency and low levels of testosterone hormone. Ionizing radiation produces harmful effects on the organisms and due to the wide spread use of radiation in diagnosis therapy, industry, therefore, pharmacological intervention could be most potent strategy to protect human or ameliorates the deleterious effect of ionizing radiation (Kumar and Tiku, 2016). Blue-green algae (BGA) have 
attracted attention as health beneficial foods and as source time of the experiment. materials for drug development (Schaap et al., 2012). The most common BGA, Spirulina platensis (SP) and Aphanizomenon flos-aquae (AFA) were found to have antioxidant (Venkatesan et al., 2012), anti-inflammatory and hypolipidemic properties (Yang et al., 2011; El-Depsi, 2016). The blue-green algae (Spirulina sp., Aphanizomenon flos-aquae and Chlorella sp.) are commercially distributed as organic algae dietary supplements. They have significant amounts of lipid, protein, chlorophyll, carotenoids, vitamins, calculated according to the Paget's formula on the basis of minerals and unique pigments. They may also have potent the human dose (Paget and Barns, 1964).

probiotic compounds that enhance health (Singh et al., 2005; $\mathrm{Wu}$ et al., 2012). Aphanizomenon flos-aquae (AFA), is a fresh water unicellular blue-green algae that spontaneously grows in Upper Klamath Lake (Germany) and that is consumed as a nutrient-dense food source and for its healthenhancing properties (Pugh and Pasco, 2001). AFA is an important source of the blue photosynthetic pigment phycocyanin (PC), which has been shown to have potent antioxidant activity, scavenge preoxynitirite and to inhibit cyclooxygenase 2 and thus have the potential to reduce inflammation (Scoglio et al., 2014; Li et al., 2016). AFA is an exceptional source of carotenoids (more than 240 retinol equivalents per gram). Beta-carotene, as well as other carotenoids, has been shown to be powerful antioxidants which help in the prevention of cardiovascular diseases and cancer (Khuantrairong and Traichaiyaporn, 2012). Recently, blue-green algae (Spirulina) have been reported to have multiple beneficial effects in improving productive and reproductive performance of animal and poultry (Shanmugapriya et al., 2015).

\section{Materials and Methods}

A total of forty eight male albino rats (Rattus rattus) weighing 180-200 gm, purchased from the Egyptian Holding Company for Biological Products and Vaccines (Cairo-Helwan, Egypt), were used as experimental animals for the different investigations carried out in this work. The animals were kept in the laboratory for 2 weeks before the experimental work and they were housed in especially designed cages, 6 rats per cage, with controlled air, temperature and relative humidity. The animals were fed standard rodent pellets. Food and water were made available ad-libitum throughout the whole experimental period. Animals were acclimatized to laboratory conditions before starting the experiment. All animals procedure were consistent with the guidelines of Ethics by Public Health Guide for the Care and Use of Laboratory Animals (National Research Council, 1996).

\section{Gamma-irradiation procedure:}

Irradiation process was performed using Gamma Cell-40 achieved by Egypt's National Center for Radiation Research and Technology (NCRRT), Cairo. The gamma cell-40 is a caesium-137 irradiation unit manufactured by Atomic Energy of Canada Limited. The unit provides means for uniform Gamma-irradiation of small animals or biological samples while providing complete protection for operating personnel. The dose rate was $0.62 \mathrm{~Gy} / \mathrm{min}$ at the

\section{Aphanizomenon flos- aquae (AFA-Klamath) administration:}

AFA-Klamath capsules (350 $\mathrm{mg}$ ) purchased from German Egyptian Pharmaceutical Company. AFA capsule were opened and dissolved in distilled water. The drug was administrated orally by gastric tube at a dose of $94.5 \mathrm{mg} / \mathrm{kg}$ body weight/day for 21day. The dose for the rat was

\section{Experimental design:}

48 of the experimental animals were divided into 4 groups. These groups were.

1) Group $C$ : control rats normal healthy rats left without any treatment.

2) Group R: rats were exposed to single dose of $4 \mathrm{~Gy}$ of $\gamma$-radiation.

3) Group AFA: rats were terated orally with $94.5 \mathrm{mg} / \mathrm{kg}$ body weight/ day AFA for 3 weeks.

4) Group AFA+R: rats were administrated with $94.5 \mathrm{mg} / \mathrm{kg}$ body weight/day of AFA extract for a period of one week before and three weeks after irradiation.

The experimental rats were sacrificed after 5 and 21 days post-irradiation.

\section{Biochemical assays}

Testosterone was determined using enzyme immunoassay test kit Bio Check, U.S.A (catalog number: BC-1115) and level of lipid peroxidation (LPO) in testis tissues were determined according to the method of Yoshioka et al. (1979).

\section{Histological and histochemical techniques}

The animals of the control and treated groups were sacrificed after five and twenty one days post-irradiation, then the testes were immediately excised and fixed in $10 \%$ neutral formalin for 24 hours followed by dehydration in ascending grades of alcohol, clearing in xylene and embedding in paraffin wax. Sections were then cut at $5 \mu$ thickness and stained by haematoxylin and eosin stain according to the method reported by Bancroft and Gamble (2002). Collagen fibres were stained by using Mallory's trichrome stain (Pears, 1977). Polysaccharides were detected by using periodic acid Schiff's (PAS) reagent (Drury and Wallington, 1980). Total proteins were detected by using mercuric bromophenol blue method (Mazia et al., 1953). DNA was detected by using Feulgen reaction (Drury and Wallington, 1980). Amyloid- $\beta$ was detected by Congo red technique (Valle, 1986).

\section{Quantitative histochemical analysis}

The optical density of histochemical stained sections in testes for carbohydrates, total protein, nucleic acid DNA and Amyloid- $\beta$ protein of the control and treated groups was recorded using IPWIN 32 image analysis software.

\section{Statistical analysis}


Statistical analyses were performed using analyses of variance (ANOVA) according to Snedecor and Cochran (1980). The data were processed and analyzed using the SPSS software (Statistical Analysis for Social Science, Version 8). Significant differences between treatment means were determined by student t-test. Data were presented as mean $\pm \mathrm{SE}$ and $\mathrm{P}<0.05$ was considered statistically significant.

\section{Results}

\section{Biochemical results}

Data in figs. 1,2 revealed that there are highly significant decrease $(\mathrm{P}<0.01)$ in the mean values of serum (free and total) testosterone levels in animals exposed to $\gamma$ radiation on 5 and 21 days post irradiation. Animals received AFA extract alone showed non significant differences in the whole set of biochemical parameters compared with the control group. The rats treated with AFA exhibited non significant decrease in mean value of serum testosterone.Very highly significant increase $(\mathrm{p}<$ 0.001 ) was detected in tissue MDA level in rats exposed to $\gamma$-radiation on 5 and 21 days post irradiation, but administration of AFA to the irradiated rats showed non significant increase in the mean value of MDA (Fig. 3).

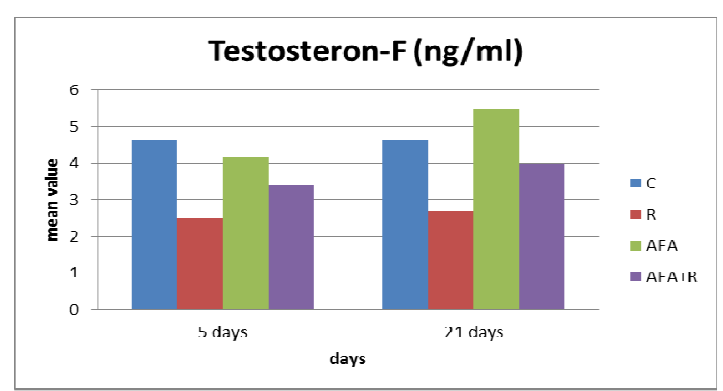

Fig. 1-Effect of radiation and/ or AFA on serum free testosterone $(\mathrm{ng} / \mathrm{ml})$ of the control and all the treated groups of adult male albino rats.

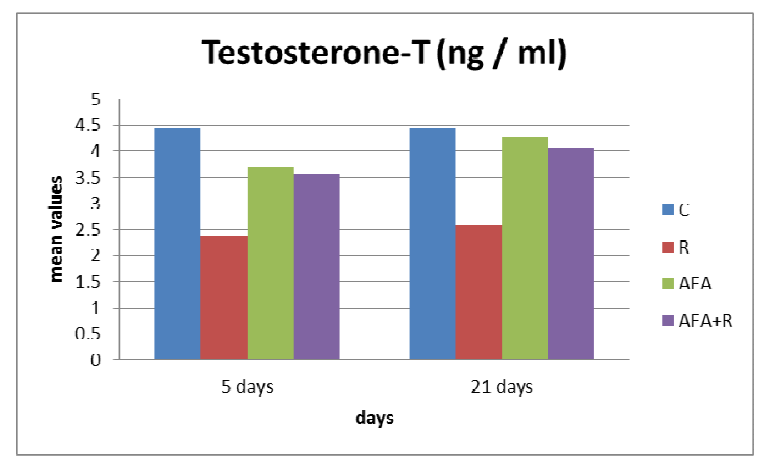

Fig. 2 - Effect of radiation and/ or AFA on serum total testosterone (ng/ml) of the control and all the treated groups of adult male albino rats.

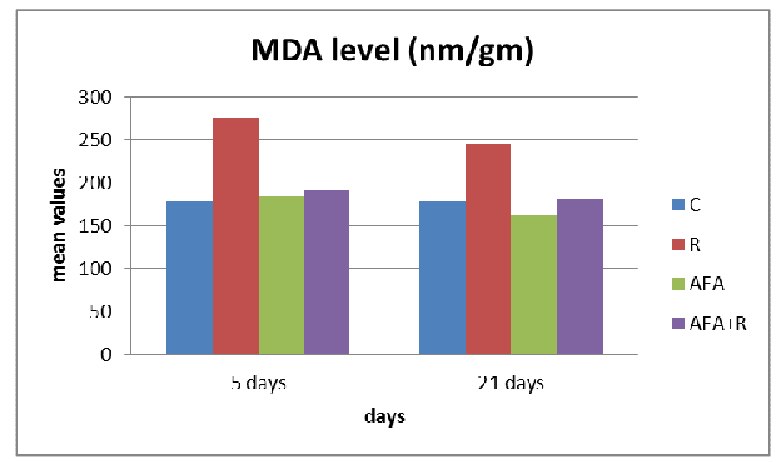

Fig. 3- Effect of radiation and/ or AFA on testicular malondialdehyde levels $(\mathrm{nm} / \mathrm{mg})$ of the control and all the treated groups of adult male albino rats.

\section{Histopathological observations:}

The control group C: light microscopic examination of the stained sections of testes illustrated the normal architecture of the seminiferous tubules, basement membranes, spermatogenic cells, normal sperms and interstitial Leydig cells (Figs. 4\&5). Irradiated groups R: sections from testes excised five days after exposure to a single dose of $\gamma$-radiation showed disturbed spermatogenic layers with vacuolated spermatogenic cells, presence of polynucleated cells, absence of mature sperms, oedema in the interstitial spaces, congested testicular arteries with thickened, dilated and corrugated walls of them, they also contained hemolysed blood cells with highly reduced, atrophied and distorted Leydig cells in the interstitial spaces (Figs. 6-9).

Testes of animals excised 21 day after exposure to a single dose of $\gamma$-radiation showed highly elongated walls of the congested blood vessels, thickened capsule with debris of degenerated spermatogenic layers and cells, oedema in between the seminiferous tubules with disappearance or highly reduced and distorted Leydig cells (Figs. 10-12).

AFA groups: testes of these groups showed well developed architecture of the seminiferous tubules and Leydig cells in the interstitial spaces with highly increased mature sperms (Figs. 13\&14) after 5and 21days of treatment respectively . $\mathrm{AFA}+\mathrm{R}$ groups: testes of group $\mathrm{AFA}+\mathrm{R}$ showed increased cellularity of the spermatogenic layers in the seminiferous tubules especially the mature sperms with normal appearance of Leydig cells and their blood vessels after 5 days of $\gamma$-irradiation (Fig. 15). Most of seminiferous tubules appeared normal with increased number of mature sperms after 21 days of $\gamma$-irradiation (Fig. 16).

Mallory's trichrome stained sections of the testes of the control group showed normal distribution of the collagen fibres supporting cellular membranes of the spermatogenic layers, Leydig cells, basement membranes of the seminiferous tubules and the connective tissue (Fig. 17).

Irradiated groups (R) showed highly increased collagen fibres under the testicular capsule, basement membranes, Leydig cells and around the blood vessels with signs of fibrosis in the capsule and some seminiferous tubules (Figs $18 \& 19)$ after 5and 21 days of irradiation respectively.

AFA groups showed normal appearance of collagen fibres in the seminiferous tubules, their basement membranes and in mature sperms with no signs of fibrosis (Figs. 20\& 21) after 5and 21days of treatment respectively.

Slightly decreased collagen fibres in and around the seminiferous tubules of testis tissue in AFA+R groups (Figs. 22\& 23) after 5and 21days of treatment respectively were observed. 
Histochemical observations and image analysis of the testes Polysaccharides

Fig. 24: showing normal distribution of PAS +ve materials (magenta color) in the testicular tissue of a control (C) group where moderate staining affinity is seen in the basement membranes of the seminiferous tubules and Leydig cells with deeply stained heads of mature sperms. Exposure of rats to $4 \mathrm{~Gy}$ of gamma radiation (R) showed a significant decrease in the PAS +ve materials in the testis of a rat after 5 days (Fig. 25) or 21 days (Fig. 26) of $\gamma$ irradiation, but they increase in the basement membranes of the seminiferous tubules. Normal distribution of PAS +ve materials in the testicular tissues of rats of AFA groups after 5 days (Fig. 27) or 21 days (Fig. 28) of the treatment. Treatment of experimental animals by AFA followed by $\gamma$ irradiation showed somewhat normal distribution of PAS +ve materials in the testicular tissues of AFA+R groups after 5 days (Fig. 29) or 21 days (Fig. 30) of $\gamma$ - irradiation.

Image analysis of PAS +ve materials showed that gamma irradiation caused marked diminution $(\mathrm{P}<0.01)$ of mean value of polysaccharides content in the testicular tissue ( $0.246 \& 0.233$ after 5 days or 21 days of $\gamma$ - irradiation respectively) as compared to control value $(0.325 \pm 0.032)$. However, AFA treated groups showed a non significant increase $(\mathrm{P}<0.05)$ in mean value of PAS positive $(0.345 \&$ 0.365 after 5 and 21 days of the treatment respectively) as compared to control value. A non significant increase $(\mathrm{P}<$ $0.05)$ was also detected in $A F A+R$ groups and nearly reached the control value $(0.325 \pm 0.032)$ (Fig. 31$)$.

\section{Total protein}

Figure 32: showing normal distribution of total protein in the testicular tissue of a control rat represented by deeply stained granules inside the nuclei and cytoplasm of all the spermatogenic cells. The boundaries of the seminiferous tubules as well as intertubular connective tissue showed strong mercury bromophenol blue reaction. However, decreased staining affinity of total protein was noticed in the testicular tissue of the irradiated group (Figs $33 \& 34$ after 5 or 21 days of $\gamma$ - irradiation respectively). Normal appearance of total protein in the testes of rats of AFA groups after 5 days (Fig. 35) or 21 days (Fig. 36) of the treatment. To some extent, normal appearance of the total protein was detected in $\mathrm{AFA}+\mathrm{R}$ groups after 5days (Fig. 37) or 21 days (Fig. 38) of $\gamma$ - irradiation.

Mean optical density values showed significant decrease $(\mathrm{P}<0.05)$ in total protein $(0.26 \& 0.25$ after 5 and 21 days post $\gamma$ - irradiation respectively) in the irradiated groups as compared to that of the control value $(0.35 \pm 0.023)$; whereas a non significant increase $(\mathrm{P}<0.05)$ in total protein content was detected in AFA group which reached to $0.33 \& 0.35$ after 5 and 21 day of the treatment respectively as compared to control value. The animals which were treated with AFA followed by $\gamma$ - irradiation represented non significant change $(\mathrm{P}<0.05)$ in total protein value $(0.36 \&$ 0.33 after 5 and 21 days of $\gamma$-irradiation respectively in the testis) in a degree more or less similar to that of the control value (Fig. 39).

DNA

The nuclei of the cells of testicular tissue of the control rats showed normal distribution of DNA in the form of granules of magenta color in the nuclei of all spermatogenic cells. Strong reaction is also seen in the interstitial cells and Sertoli cells (Fig. 40). Exposure of rats to gamma radiation showed a noticeable reduction in DNA content of the nuclei in the testicular tissue after 5 days (Fig. 41) or 21 days (Fig. 42) of $\gamma$ - radiation exposure compared to DNA content of the control group. The testicular tissue of AFA treated groups showed normal appearance of DNA content after 5 days (Fig. 43) or 21 days (Fig. 44) of the treatment. AFA+R groups showed somewhat normal distribution of DNA content in the testicular tissues after 5days (Fig. 45) or 21 days (Fig. 46) of $\gamma$-irradiation.

Optical density measurements showed significant decrease $(\mathrm{P}<0.05)$ in mean value of DNA content post-exposure to radiation $(0.24 \& 0.27$ after 5 or 21 days of $\gamma$ - irradiation respectively) as compared to that of the control value $(0.33 \pm 0.036)$. Also, a non significant decrease $(\mathrm{P}<0.05)$ in mean value of DNA content was noted in AFA treated group $(0.32 \& 0.32$ after 5 and 21 days of the treatment respectively) as compared to that of the control value; whereas AFA+R groups showed a non significant change in mean value of DNA content $(0.31 \& 0.34$ after 5 and 21 days of $\gamma$ - irradiation respectively) as compared to control value (Fig.47).

\section{Amyloid- $\beta$ protein:}

Figure 48: showing pale to moderately stained amyloid protein in the spermatogenic cells and Leydig cells of rats of the control group. Exposure of rats to gamma radiation showed highly increased amyloid $\beta$-proteins in the testicular tissues especially in the thickened wall of the congested testicular artery and the hemolysed blood cells after 5 days (Fig. 49) or 21 days (Fig. 50) of $\gamma$-radiation exposure. Moderate staining affinity of amyloid protein in the basement membranes of the seminiferous tubules and Leydig cells with deeply stained heads of mature sperms in the AFA groups after 5 days (Fig. 51) or 21 days (Fig. 52) of the treatment. AFA+R groups showed somewhat normal appearance of the amyloid $\beta$-protein in the testicular tissue after 5 days (Fig. 53) or 21 days (Fig. 54) of $\gamma$-irradiation.

Mean optical density values showed significant increase $(\mathrm{P}<0.05)$ in amyloid protein content $(1.12 \& 85$ after 5 or 21 days of $\gamma$-irradiation respectively) in the irradiated group as compared to that of the control value $(0.41 \pm 0.059)$; whereas a non significant change $(\mathrm{P}<0.05)$ in amyloid protein content was detected in AFA group which reached to $0.41 \& 0.41$ after 5 and 21 days of the treatment respectively as compared to control value. A significant increase $(\mathrm{P}<0.05)$ in the mean value of amyloid protein content was detected in $\mathrm{AFA}+\mathrm{R}$ groups which reached 0.48 after 5 days, but after 21 days of $\gamma$ irradiation there was non significant increase (Fig.55). 

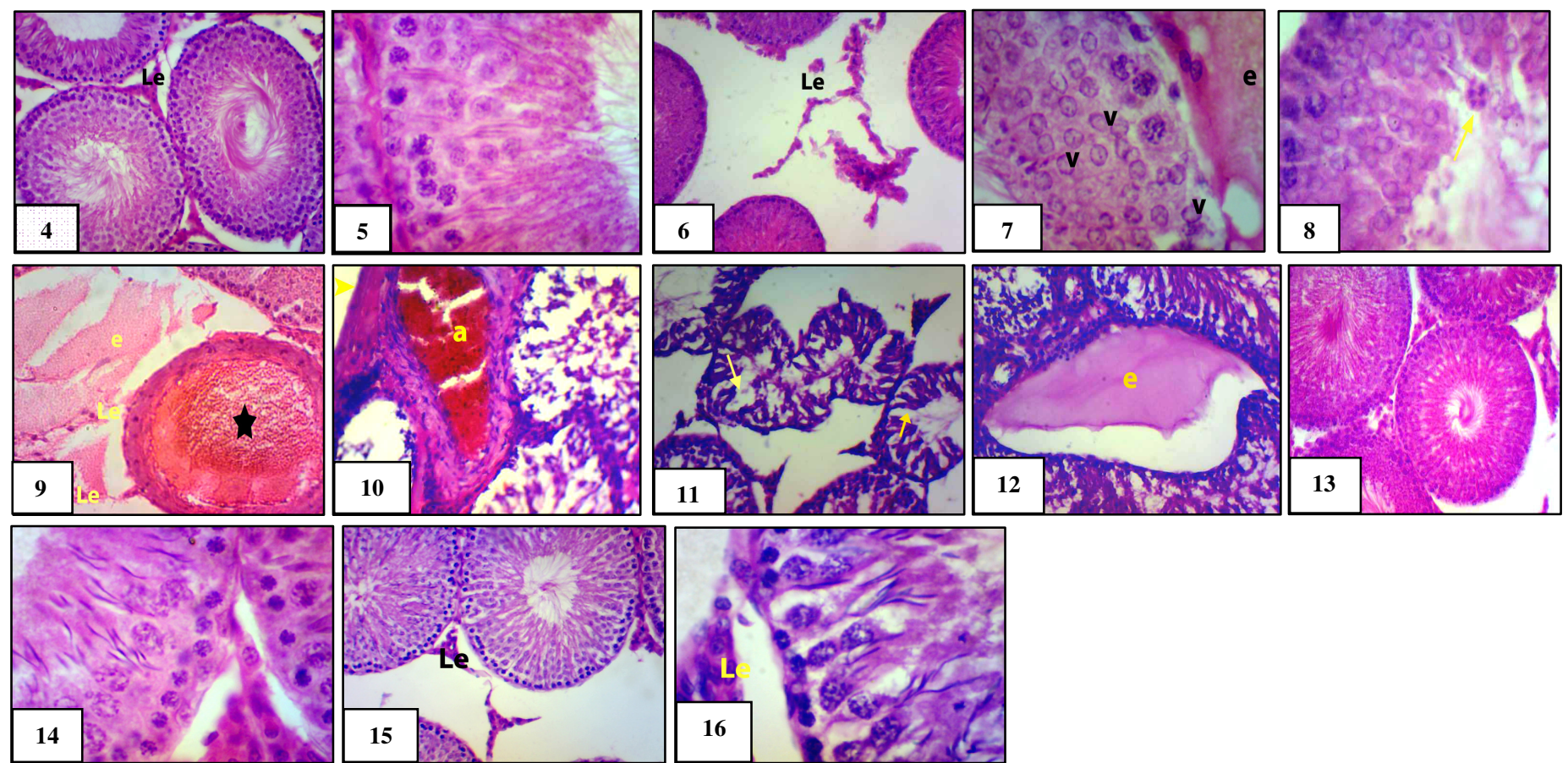

Figs. 4\&5: well developed spermatogenic layers and Leydicg cells (Le) in the interstitial spaces of testis tissue of a control rat. (4, H\&E X 200 \&5, H\&E X 400). Figs. 6-9: testes tissues of the irradiated group after 5days showing: disturbed spermatogenic layers with vacuolated spermatogenic cells (v), presence of polynucleated and gaint cells ( $\boldsymbol{\nabla}$, absence of mature sperms, oedema in the interstitial spaces (e), congested testicular artery with thickened, dilated and corrugated wall of it and it also contains hemolysed blood cells ( with highly reduced, atrophied and distorted Leydig cells (Le) in the interstitial spaces. (6, $9 \mathrm{H} \& \mathrm{E}$ X $200 \& 7,8 \mathrm{H} \& \mathrm{E}$ X 400). Figs. 10-12: testes of the irradiated group after 21 days showing highly congested and dilated testicular artery (a), thickened capsule ( $\square$ ) with debris of degenerated spermatogenic layers, cells ( $\boldsymbol{\lambda}$, oedema (e ) in between the seminiferous tubules, disappearance or highly reduced and distorted Leydig cells in the interstitial space. (H\&E X 200). Figs.13\&14: normal architecture of the spermatogenic layers and their cells inside the seminiferous tubules and Leydig cells in the interstitial spaces of testes of AFA groups. (13H\&E X $200 \& 14 \mathrm{H} \& \mathrm{E}$ X 400) afrer5 and21days of treatment respectively. Figs. 15\& 16: increased cellularity of the spermatogenic layers in the seminiferous tubules especially mature sperms, normal Leydig cells (Le) with normal appearance of blood vessels of testes of rats of AFA+R groups ( 15 H\&E X $200 \& 16$ H\&E X 400) afrer5 and 21days of irradiation respectively.
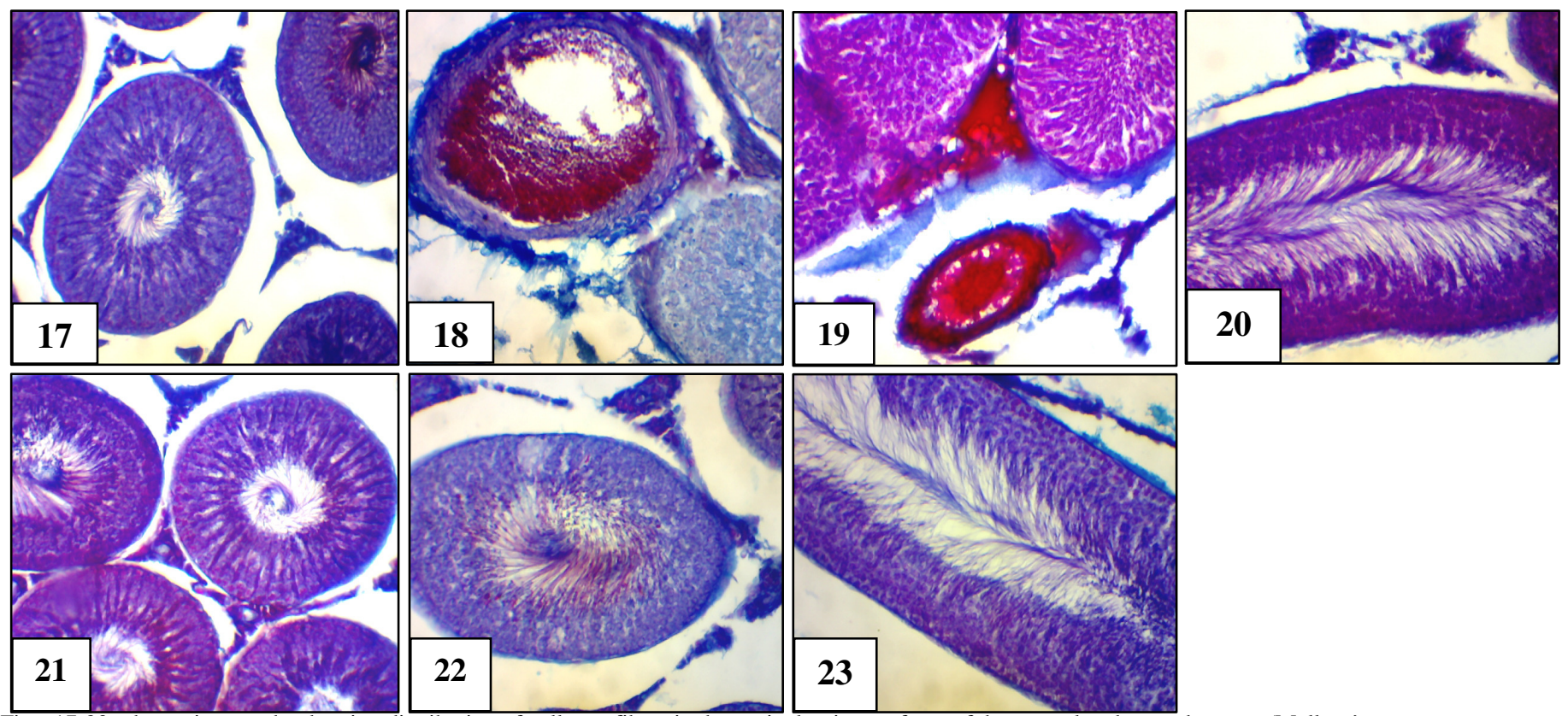

Figs. 17-23: photomicrographs showing distribution of collagen fibres in the testicular tissue of rats of the control and treated groups (Mallory's trichrome stain X 200). Fig. 17: normal distribution of collagen fibres which support cellular membranes of the spermatogenic cells, Leydig cells, basement membranes of the seminiferous tubules and connective tissue of the testis of the control group. Figs. 18\& 19: highly increased collagen fibres under the testicular capsule, basement membranes, Leydig cells and around the blood vessels with signs of fibrosis in the capsule and some seminiferous tubules in the irradiated groups (after 5 and 21 days post-irradiation respectively). Figs. 20\& 21: normal distribution of collagen fibres in the seminiferous tubules and their basement membranes and in mature sperms in the testes of AFA groups after 5 or 21 days of the treatment respectively. Figs. 22\& 23: slightly decreased collagen fibres in and around the seminiferous tubules of testes of AFA+R group after 5 or 21 days of the irradiation respectively. 

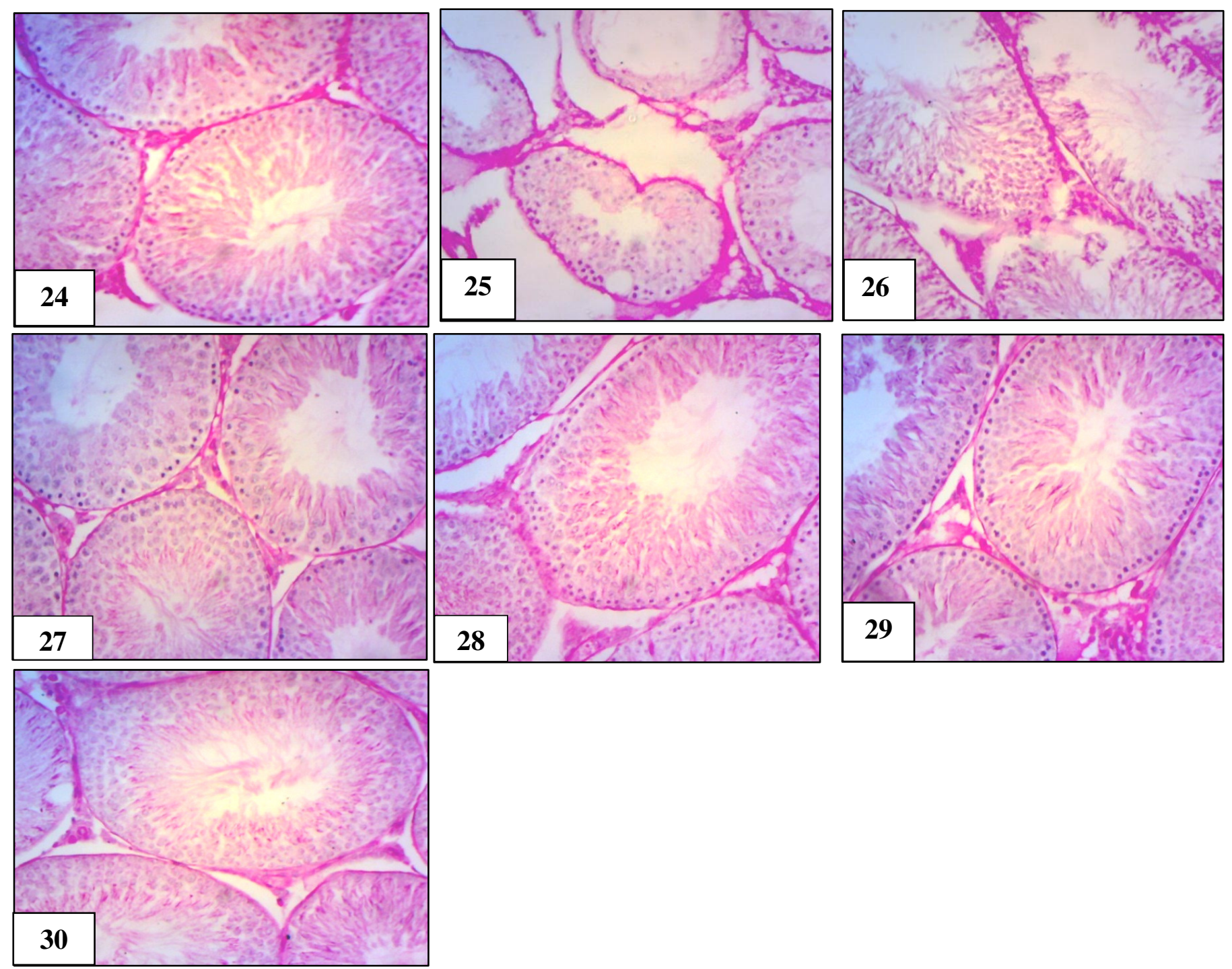

Figs. 24-30: photomicrographs showing distribution of PAS + ve materials in the testicular tissue of rats of the control and treated groups (PAS X200) Fig. 24: normal distribution of the PAS +ve materials in the seminiferous tubules of the control group. Figs. 25\& 26: testicular tissue of the R group showing reduced PAS +ve materials inside the seminiferous tubules after 5 or 21 days of the irradiation respectively. Figs. 27-28: showing normal distribution of PAS +ve materials in the testicular tissues of rats of AFA groups after 5 or 21 days of the treatment respectively. Figs. 29\&30: showing somewhat normal distribution of PAS + ve materials in the testicular tissues of AFA+R groups after 5 or 21 days of the irradiation respectively.

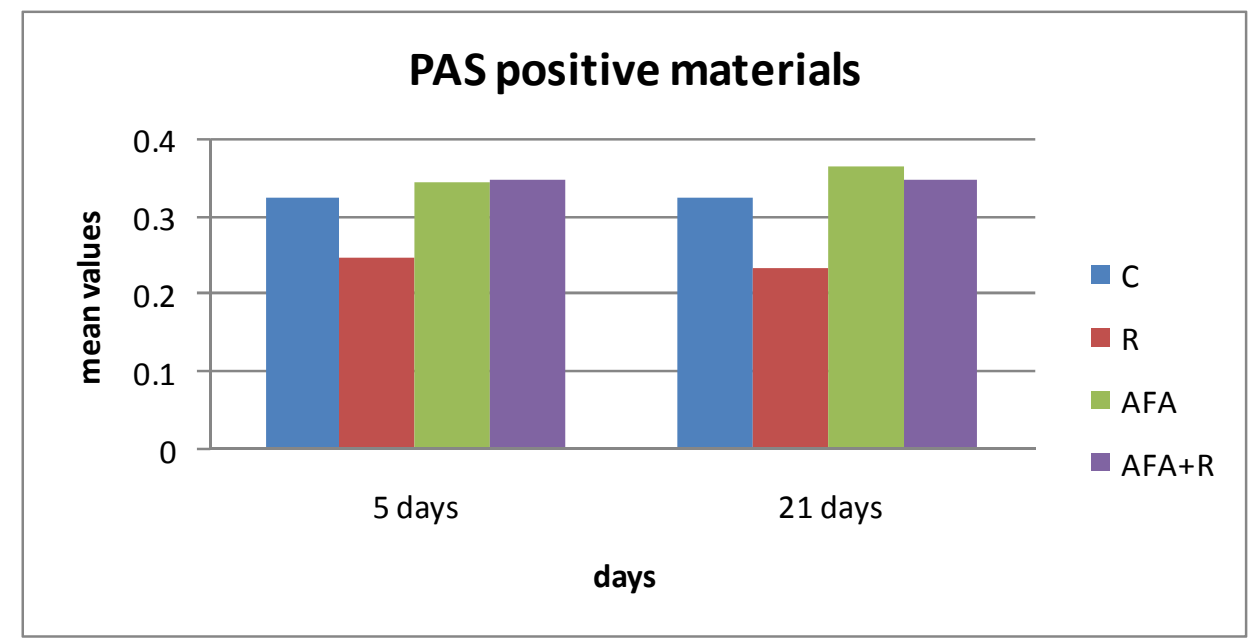

Fig. 31- Effect of radiation and/ or AFA on the mean optical density values of PAS +ve materials in the testes of adult male albino rat. 

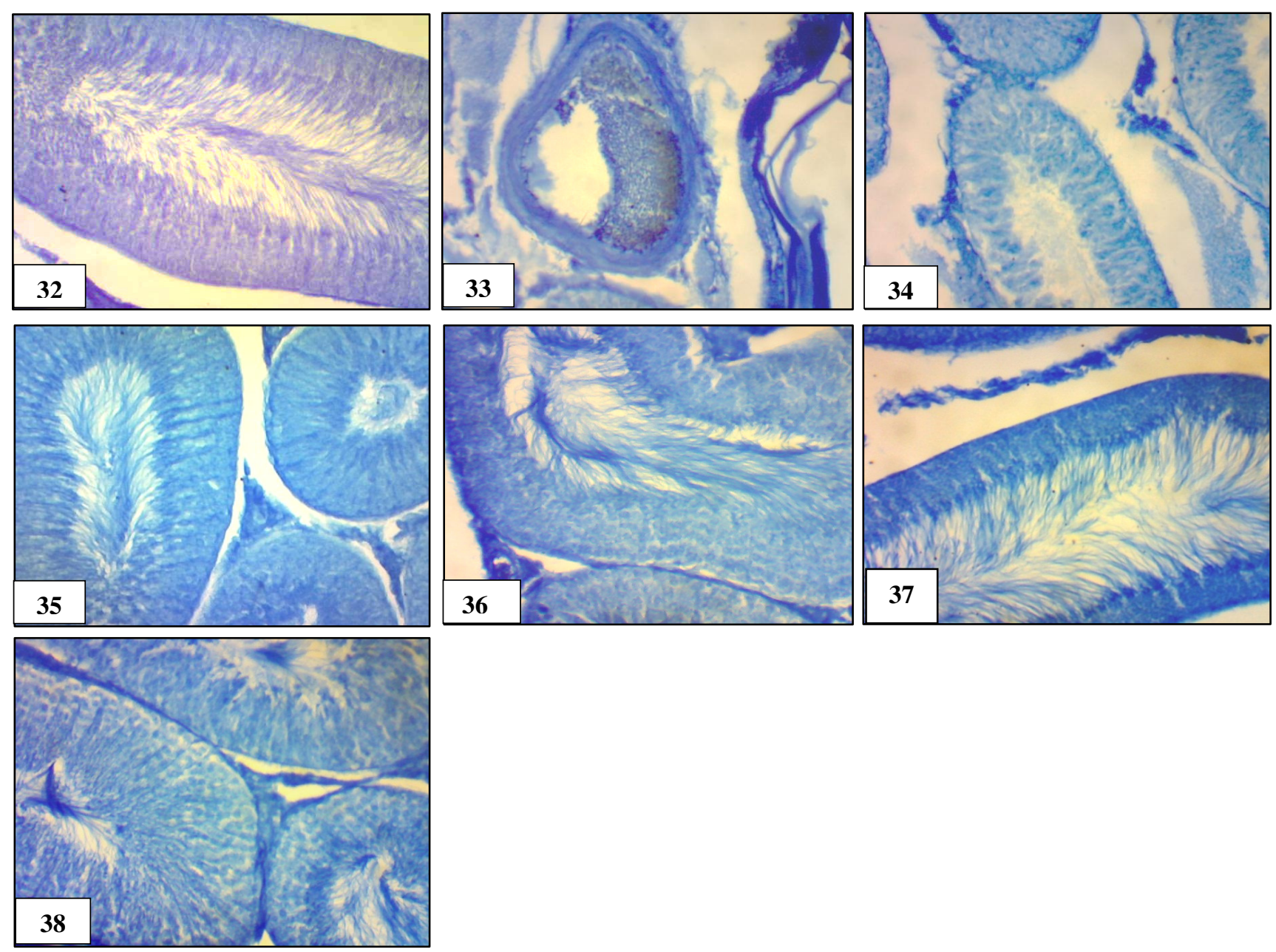

Figs.32-38: photomicrographs showing distribution of the total protein in the testicular tissue of rats of the control and treated groups (Bromophenol blue X 200).

Fig. 32: showing normal distribution of the total protein in the testicular tissue of a control rat. Figs. 33\&34: showing decreased total protein in the testes of rats of the irradiated group after 5 or 21 days of the irradiation respectively, but they increase in the thickened wall of the congested testicular artery and the hemolysed blood cells after 5 days (Fig. 33) of $\gamma$ - irradiation. Figs. 35\& 36: showing normal appearance of total protein in the testes of rats of AFA groups after 5 or 21 days of the treatment respectively. Figs. 37\& 38: photomicrographs showing somewhat normal distribution of total proteins in the testicular tissues of AFA+R group after 5 or 21 days of $\gamma$ - irradiation respectively.

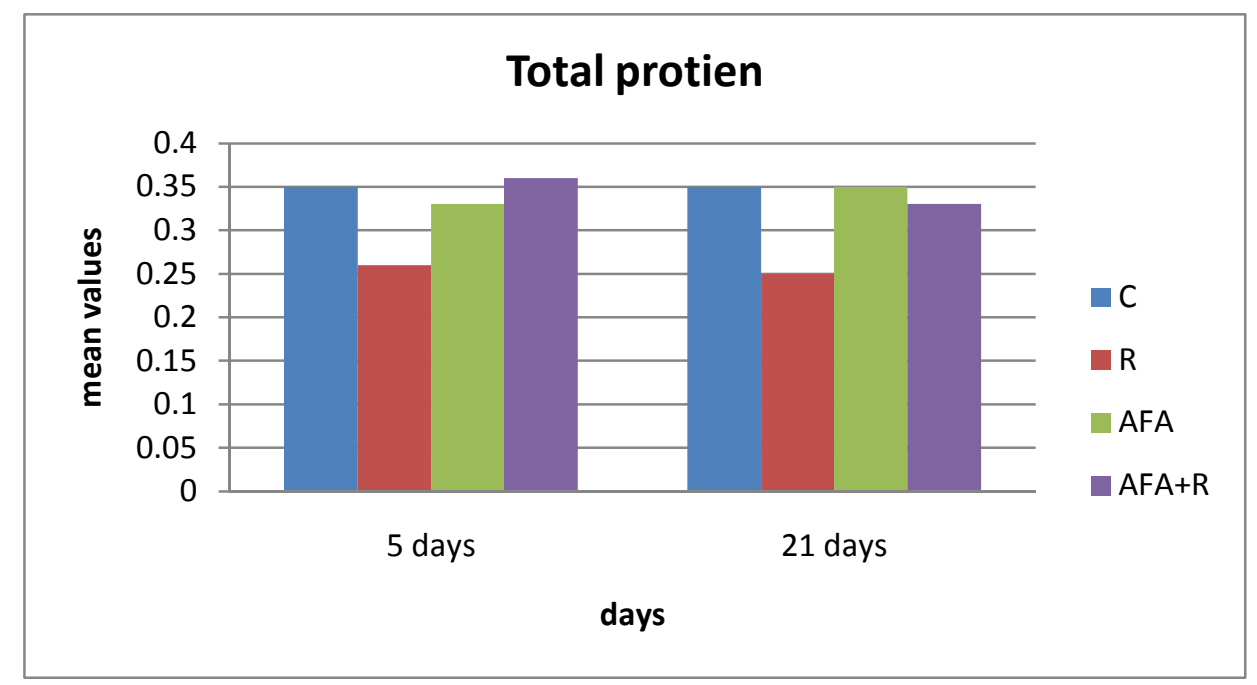

Fig. 39- Effect of radiation and/ or AFA on the total protein content in the testes of adult male albino rats. 

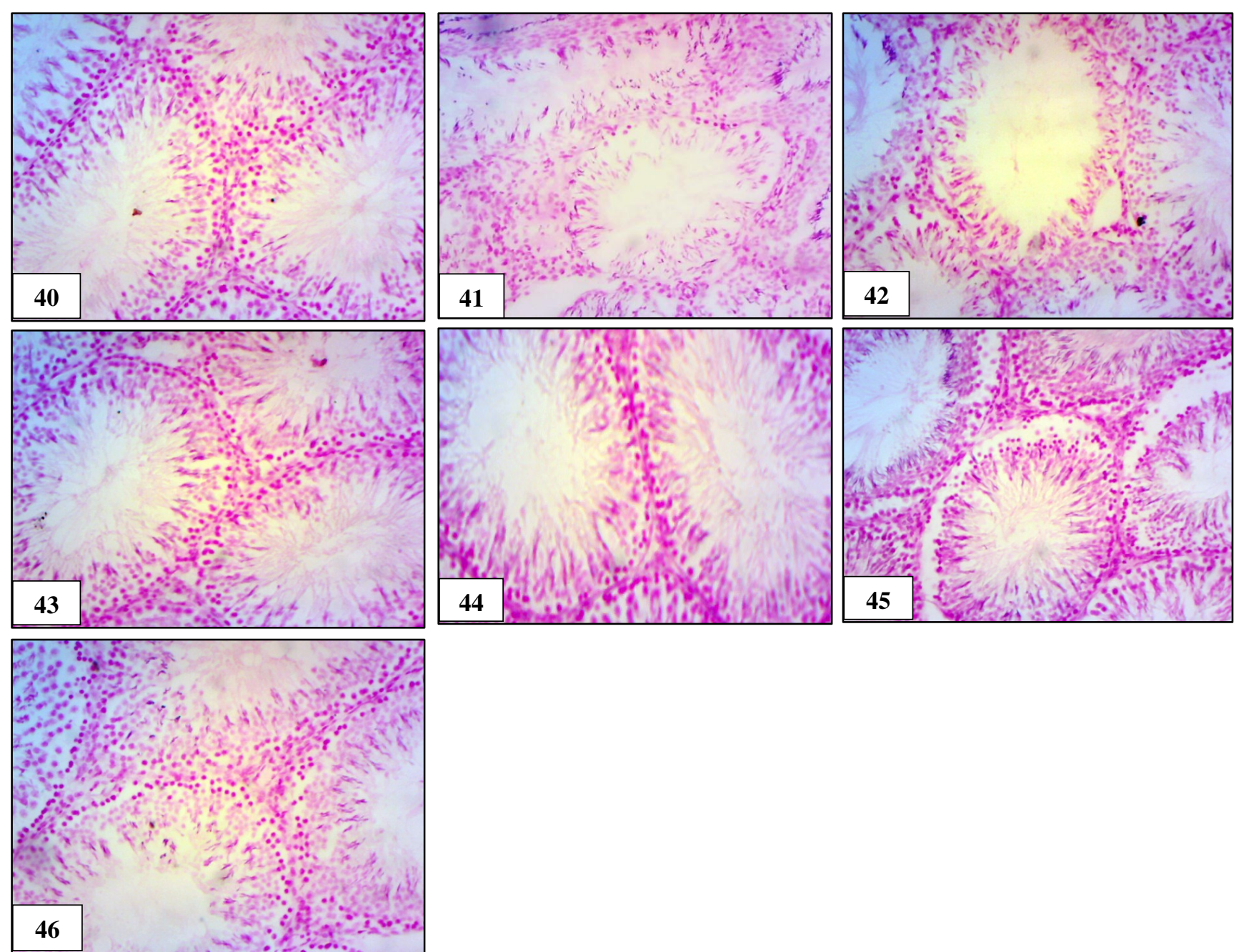

Figs.40-46: photomicrographs showing distribution of the DNA content in the testicular tissue of rats of the control and treated groups (Feulgen stain X 200).

Fig. 40: normal distribution of the DNA content in the nuclei of spermatogenic cells and Leydig cells of the control group. Figs. 41\& 42: testicular tissue of R groups showing decreased DNA content of the nuclei of spermatogenic cells and Leydig cells after 5 and 21 days post-irradiation respectively. Figs. 43\& 44: testicular tissue of AFA groups showing normal appearance of DNA content in the testicular tissues of AFA groups after 5 or 21 days of the treatment respectively. Figs. 45\& 46: testicular tissue of AFA+R groups showing somewhat normal content of DNA materials in the different spermatogenic cells and Leydig cells after 5and 21 days post-irradiation respectively.

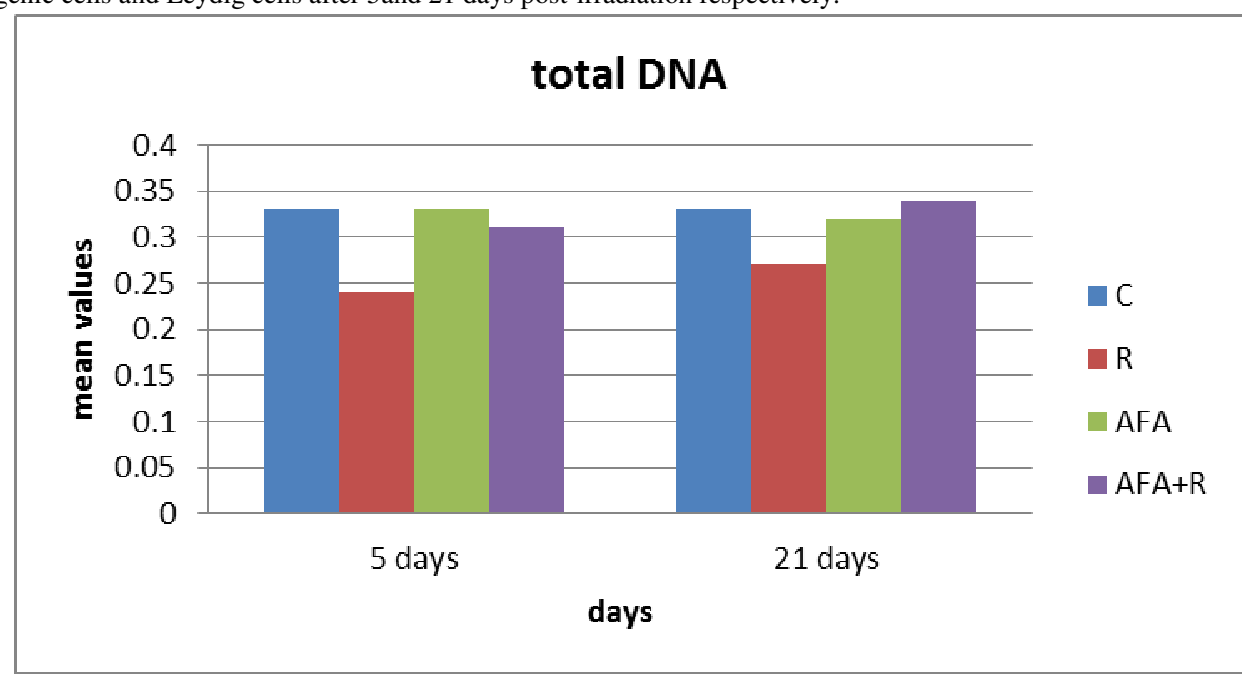

Fig. 47 - Effect of radiation and/ or AFA on the total DNA content in the testes of adult male albino rats. 

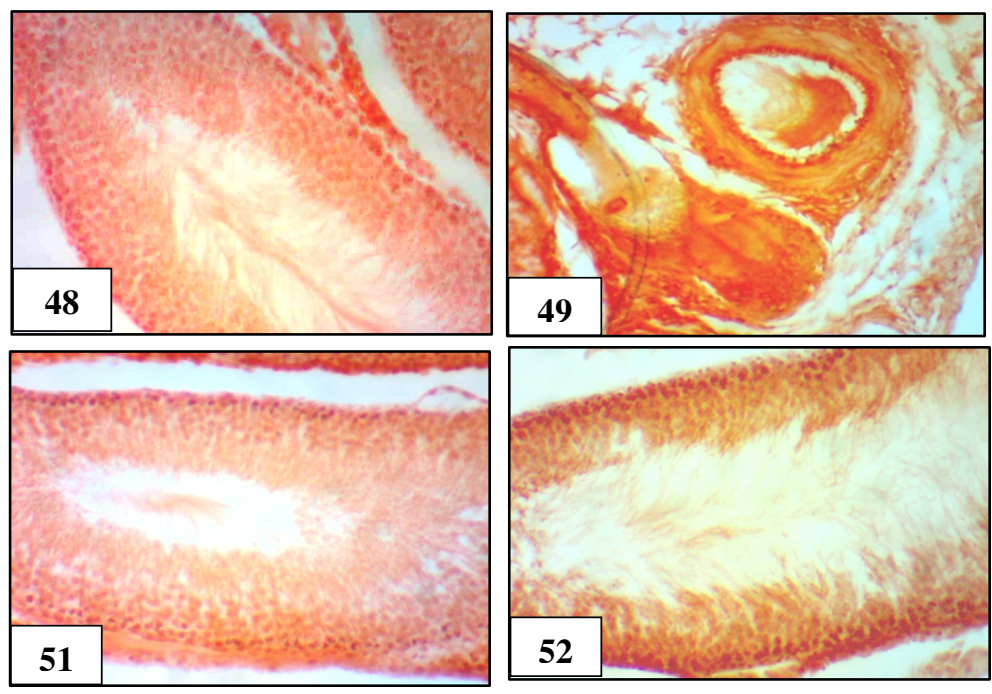
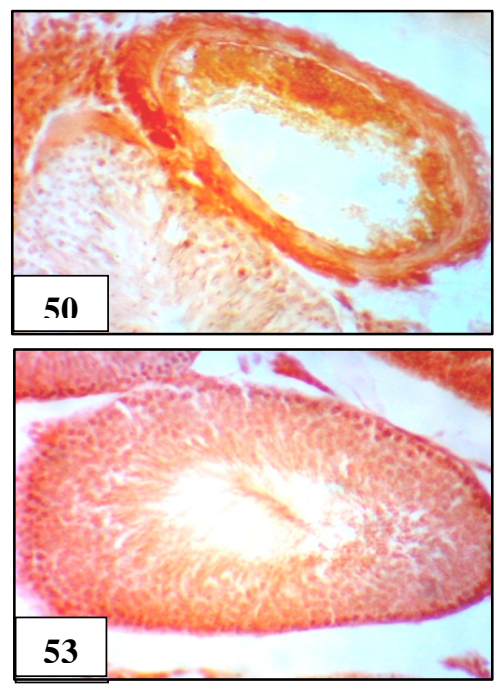

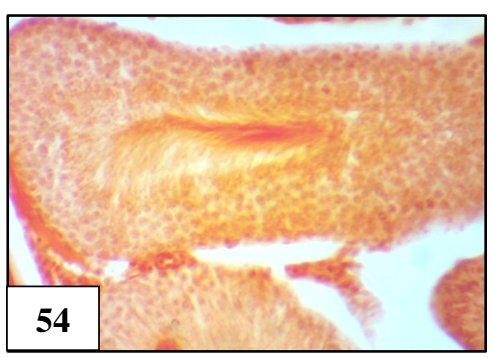

Figs.48-54: photomicrographs showing appearance of the amyloid $\beta$-protein in the testicular tissue of rats of the control and treated groups (Congo red stain X 200).

Fig. 48: showing pale to moderately stained amyloid protein in the spermatogenic cells and Leydig cells of testes of the control group. Figs. 49\& 50: showing highly increased amyloid $\beta$ - proteins in the testicular tissues of the irradiated group especially in the thickened wall of the congested testicular artery and the hemolysed blood cells after 5or 21 days of $\gamma$ - radiation exposure respectively. Figs. 51\& 52: showing normal appearance of the amyloid $\beta$ - protein in the testicular tissue of AFA group after 5 and 21 days of treatment respectively. Figs. 53\&54: showing somewhat normal appearance of the amyloid $\beta$ - protein in the testicular tissue of AFA+R group after 5or 21 days of $\gamma$ - irradiation respectively.

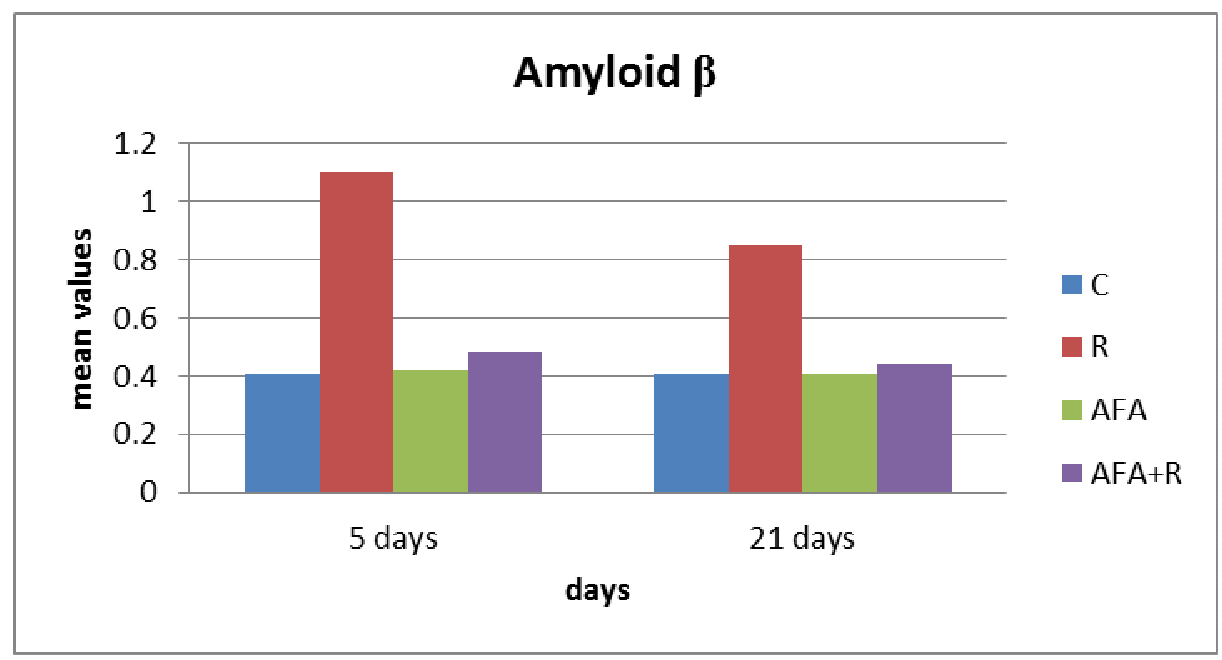

Fig. 55- Effect of radiation and/ or AFA on the amyloid $\beta$-protein in the testes of adult male albino rats. 


\section{Discussion}

Radiation illness is defined as the damage to the organ tissues due to the excessive exposure to ionizing radiation. The exposure to radiation interferes with the process of cell division (Donnely et al., 2010).

Testes were studied for their high sensitivity to radiation (Akdag et al., 2016).The germinal cells of the testes are recognized as the first radiosensitive site among body organ and tissue because of the presence of rapidly proliferating cells and spermatogonia (Samarth and the Samarth, 2009). The male hormone testosterone, derived
mainly from the testis, is an anabolic and androgenic steroid responsible for the production of male physical feature and promotes spermatogenesis (Luo et al., 2011).

In this study, a marked significant decrease in serum testosterone was observed in the irradiated rats. This result is in agreement with those of Abdelhafez (2008); Ibrahim and Ghoneim (2014) and Shetty et al. (2016) who reported a decrease in testosterone in serum of irradiated rats. Testicular exposure to ionizing radiation in animal induced significant changes in serum gonadotrophins and semen parameters. The present data revealed that irradiation induced a decrease in testosterone level. This may be due to Le impairment in Leydig cell function. In addition, Liu et al. (2005) referred these changes to the influence on cell steroidogenesis resulting in reduction of testosterone.The decrease in the testosterone level seems to be due to a reduction in the activity of enzymes involved in the biosynthesis of testosterone or due to the decrease in testicular cholesterol, a precursor of testosterone synthesis (McVey et al., 2008).

In the present study treatment of the exposed group with AFA caused improvement in the testosterone level.

There are no available researches which concerning the radioprotective role of AFA on the mammalian testes, apc so we used Spirulina from the same family as references. This result is in agreement with those of Nah et al. (2012) who demonstrated the effective role of Spirulina maxima extract (SME) in improving the fertility of diabetic male we rats where Spirulina maxima intake for 4 weeks significantly increased testicular and body weights with normal seminiferous tubules and Leydig cell numbers and also enhanced metabolic parameters and testosterone levels in the streptoztocin (STZ) treated rats.

Results of the present study showed a significant increase in MDA level in the testicular tissues of rats of the irradiated group when compared to the control group all over the experimental period.Exposure to ionizing radiation caus induced lipid peroxidation as indicated by an increase of oxy MDA concentration in rat testes as reported by Abdelhafez (2008) and Odac et al. (2016). Results of the present study come in agreement with the results of Ibrahim and Ghoneim (2014) who revealed that whole body exposure to two doc fractionated doses $(20 \& 60 \mathrm{mGy})$ of $\gamma$-radiation caused a this significant increase in MDA level in the testis tissue. mor Radiation induced ROS and free radicals which react with the molecules of cell membranes and induce lipid architecture of the spermatogenic layers and their cells peroxidation products (MDA), which play an important role inside the seminiferous tubules and Leydig cells in the in the biological damage such as mutagenic and

carcinogenic damage (Poli et al., 2008).

In the present study supplementation of AFA to exposed rats showed good amelioration in the level of MDA in testes tissues.Gershwin and Belay (2008) reported that the antioxidant activity of phycocyanin is about 20 times more efficient than vitamin C. In addition, Spirulina contains superoxide dismutase that acts indirectly by slowing down the rate of oxygen radical generating reactions (Belay, 2002). El-Tantawy (2015) reported that the treatment of lead-intoxicated rats with Spirulina supplement revealed a significant increase in GSH level, SOD activity, decrease in MDA and NO levels as compared to lead-intoxicated rats indicating its antioxidant activity.

The current study demonstrated that rats exposed to a single dose of $\gamma$-radiation induced many histopathological changes in the testes such as disturbed spermatogenic layers with vacuolated spermatogenic cells, presence of polynucleated cells, absence of mature sperms, oedema in the interstitial spaces, congested testicular arteries with thickened, dilated and corrugated walls of them, they also contained hemolysed blood cells with highly reduced, atrophied and distorted Leydig cells in the interstitial spaces. Damaged Leydig cells observed in this study post radiation exposure ed to decreased testosterone level. These alterations resemble those reported in the experimental models of testicular damage, such as chronic testicular ischemia (Ibrahim and Ghoneim, 2014; Yokonishi and Ogawa, 2016).Exposure of animals to radiation caused a significant increase in the levels of lipid peroxidation and acid phosphatase activity (days 1 to 14 ). The histopathological results also supported the biochemical observations for massive damage to the various testicular cells (Samarth and Samarth, 2009).

In the present study, $\gamma$-irradiation treatments represented an apoptosis in the germ cells and absence of spermatogenic series. These results are in consistent with the finding of Demir et al. (2015) who reported that in case of exposure to low doses of gamma rays differentiating spermatogonia were killed. The depletion in spermatogonia resulted in a reduction in subsequent spermatozoa.

Histopathological manifestations of testicular damage in the current experiment may be due to an imbalance between the activities of an oxidant agent and the antioxidant system within the cell. It is well known that cytotoxicity is related to reactive oxygen species (ROS), superoxide radical $\left(* \mathrm{O}^{-2}\right)$, hydrogen peroxide $\left(\mathrm{H}_{2} \mathrm{O}_{2}\right)$, and hydroxyl radical $\left(\mathrm{OH}^{*}\right)$, which are produced by various factors. This link cause's oxidative damage to cell membrane, increases in oxygen radical's production and ultimately permits leakage of enzymes, leading to organ damage (Uttara et al., 2009). More recently, Akdag et al. (2016) revealed that exposure of rats to $2.4 \mathrm{GHz}$ radiofrequency $(\mathrm{RF})$ radiation (Wi-Fi) does not cause DNA damage of the organs investigated in this study. The results of this study indicated that testes are more sensitive organs to radiofrequency (RF) radiation.

Results of the present study showed normal 
interstitial spaces of testes of AFA group. These results are supported by the results of Salazar et al. (1996) who that the treatment with blue green algae (Spirulina maxima)

Abd El-Hady and El-Tahawy (2015) found that the were not associated with any adverse effects on testes of rats exposed to $950 \mathrm{MHz}$ mobile phone radiation reproductive performance, including male and female for two hours during a period of two months $2 \mathrm{hrs} / \mathrm{day}, 3$ fertility and duration of gestation in rats. times/week, showed reduction of polysaccharides. The Spirulina has been reported to have multiple beneficial decrease in carbohydrate contents in the current work may effects in improving productive and reproductive be attributed to increased stress on the organs which leading performance of animal and poultry (Shanmugapriya et al., to consuming high energy in attempt to light or equalize the 2015). pressure exerted upon them. It may also be due to the

Results of the present experiment showed that release of hydrolytic enzymes from ruptured lysosomes administration of AFA to the irradiated rats resulted in under the effects of toxic agents. This opinion is supported remarkable regenerative features as most of the by the work of Sakr and Okdah (2004) and Farrag and seminiferous tubules and Leydig cells retained their normal Shalby (2007).

histological appearance in spite of the presence of numerous Present results showed that male rats received AFA empty spaces in between the spermatogenic cells after 5 have normal appearance of PAS +ve materials, better days and showed somewhat normal testicular architecture improvement was realized in AFA administrated group may where most of the seminiferous tubules and Leydig cells be due to high percentage of immune-modulating retained their normal appearance after 21 days. In the polysaccharides in AFA. In particular, AFA seems to present study testosterone level returned nearly to its normal contain a novel type of polysaccharide that, when extracted level in group AFA+R which indicate improved and purified, has shown to be 10 times more potent in architecture of Leydig cells. $\quad$ stimulating macrophage activity than ordinary

Results of the present study come in agreement with lipopolysaccharides (LPS). Also, AFA may be able to the work carried by El-Desoky et al. (2013) who stimulate the migration of up to $40 \%$ of NK cells (Volesky demonstrated that Spirulina exhibits protective effect and Holan, 1995).

against $\mathrm{HgCl}_{2}$-induced testicular injury and sperm The current study showed that administration of the characteristics. The improvement of sperm quality may be irradiated animals with AFA represented non significant due to the antioxidant components of Spirulina, such as $\alpha$ - increase in PAS +ve materials.

tochopherol (Vitamin E), ascorbic acid (Vitamin C) and

AFA is an excellent source of $B$ vitamins including selenium that improve testicular functions and sperm appreciable amounts of vitamins $\mathrm{B}_{1}, \mathrm{~B}_{2}, \mathrm{~B}_{3}, \mathrm{~B}_{5}, \mathrm{~B}_{6}, \mathrm{~B}_{9}$ and quality. Vitamin $\mathrm{C}$ is a well-known antioxidant that is $\mathrm{B}_{12}$. In general, $\mathrm{B}$ vitamins fight stress by helping to convert present in the testes protecting it from oxidative damage polysaccharides and other carbohydrates into glucose for (Sonmez et al., 2005). Thus, it has been reported that immediately available energy, endurance and stamina the decrease in the testicular level of vitamin C are (Singh et al., 2005).

correlated with methylparathion-mediated effects on sperm Several food grade microalgae, including Spirulina quality and count in rats (Narayana et al., 2005).

platensis, Aphanizomenon flos-aquae and Chlorella

The present experiment showed an increase in pyrenoidosa are also known to contain polysaccharides with collagen fibres deposition within the seminiferous tubules potent immunostimulators of human monocytes and and Leydig cells of the irradiated rats.Increased collagen macrophages (Pugh et al., 2001).

post-radiation exposure in the testicular tissues was detected

The present study revealed highly decreased total by Abd El-Hady and El-Tahawy( 2015). Increased collagen protein content in the testicular tissue of the irradiated deposition in the current experiment could be attributed to group, but increased in thickened wall of the congested oxidative stress that stimulate the expression of genes testicular artery and the hemolysed blood cells.

involved in collagen biosynthesis (Guler et al., 2009); Decreased total protein in tissues post exposure to where increased superoxide anion formation by inhibition different types of radiations was noticed by many authors of superoxide dismutase (SOD) stimulates collagen (El Salkh, 2009; Eid et al., 2013; Abd El-Hady and Elproduction indicating a vital role of SOD and the generated Tahawy, 2015). This may be due to response of hydrogen reactive oxygen species in collagen accumulation (Lijnen et bonds of these materials to radiation (Bakhit, 2010). al., 2011).

In the current study treatment with Aphanizomenon

On the other hand, more or less normal distribution flos-aquae (AFA) showed non significant change in total of collagen fibres was detected in the testicular tissues of protein content in the testes tissue of rats. El-Depsi (2016) rats treated with AFA which may reflect the indirect anti- reported that the administration of AFA to the diabetic rats oxidant role of Aphanizomenon flos-aquae.

showed somewhat normal appearance of the total protein in Beta-carotene protects against oxidative damage of P450 the capsule, cortex and medulla of the lymph node tissue. systems in Leydig cells (Hanukoglu, 2006). AFA recovers Results of the present study showed that diabetes-induced free radical damage in spleen tissues (El- administration of AFA before and after gamma irradiation Depsi, 2016). showed somewhat normal distribution of total protein in the

Concerning the histochemical observations in the testicular tissue. current work, testes of rats exposed to 4 Gy of $\gamma$ - radiation showed reduction of polysaccharides.

Aphanizomenon flos-aquae contain more protein than any other organism (plant or animal). There are 22 amino 
acids. Spirulina is used in human nutrition because of its high protein content $(68 \%)$ and its excellent nutritive value (Becker, 2004; Farag et al., 2016).

The current results showed decreased staining affinity of DNA content in rat testicular tissue following radiation exposure. Such reduction was noticed before where, Aitken et al. (2005) showed that exposure of mice to $900 \mathrm{MHz}$ radiofrequency electromagnetic radiation induced bec DNA damage to caudal epididymal spermatozoa. The AFA

decrease in both DNA and total protein in the current work may be attributed to arrested metabolism or to use it to build up new cells or enzymes to reduce the radiation stress and also disruption of lysosomal membranes under the effect of various toxicants leading to liberating their hydrolytic enzymes in the cytoplasm and resulted in marked lysis and dissolution of the target materials (Sakr and Shalaby, 2011).These results are in agreement with those of Sakr and Okdah (2004).

In the present study somewhat normal distribution of DNA materials was demonstrated in the testicular tissue of AFA \& AFA+R groups. Values of the mean optical density confirmed the present histochemical observations and indicating the scavenging effect of AFA on free radicals produced by testes in response to ionizing radiation.

Blue-green algae (AFA) contain a wide range of antioxidants in the form of specific trace minerals, amino acids, vitamins, pigments, variety of carotenes along with phycocyanin and chlorophyl, which protects the cells from free radicals damage caused by exposure to radiation (Scoglio et al., 2014; Li et al., 2016). C-phycocyanin (CPC) can constitute up to $15 \%$ of the dry weight of a bluegreen algae harvest and contribute to the antioxidant, antiinflammatory, neuroprotective and hepatoprotective effect (Eriksen, 2008).

The current study recorded a significant increase in Practice of Histological Techniques. $5^{\text {th }}$ ed. Churchill Living the amyloid- $\beta$ protein content in the testes tissue of Stone, London, pp: 150-152.

irradiated animals.In agreement with these findings, Dasdag et al. (2012) reported that long term exposure to $900 \mathrm{MHz}$ $\mathrm{RF}$ increased amyloid $\beta$ protein and malondialdehyde levels in the brain of rats. Moreover, a study concerning the biological effect of MF $0.5 \mathrm{~T}$ at $7 \mathrm{~Hz}$ on murine brain of mice showed eosinophilic change of cytoplasm and immunohistochemical reaction to amyloid precursor protein in the neurons of the cerebral cortex (Kang et al., 1997).

The present findings indicated that administration of AFA showed normal appearance of amyloid $\beta$-protein in the testes tissue and the treatment of the exposed group with AFA showed somewhat normal appearance of amyloid $\beta$ protein in the testicular tissue. Ameliorated results in different organs of the irradiated rats which treated with AFA observed in this study may be due to antioxidant and cart anti-inflammatory effects or may be due to its ability to enhance formation of stem cells. Yang et al. (2013) reported that the anti-inflammatory function of the BGA is mediated to decrease the production of pro-inflammatory mediators. They added that BGA can also decrease oxidative stress due to their free radical scavenging activity and inhibition of lipid peroxidation.
It seems that the use of antioxidant compounds may also have a role in reducing $A \beta$ amyloid-induce toxicity. These substances include blue berries, flavonoids, polyphenols, resveratrol, Ginkgo biloba extract, epicatechin and melatonin (Massaad, 2011).

El-Depsi (2016) reported that healing of AFA diabetic rats may be due to its regenerative properties and because of antioxidant and anti-inflammatory effects of

\section{References}

Abd El-Hady, A.M. and El-Tahawy, N.A. (2015). The possible protective effect of vitamin $\mathrm{E}$ and / or silymarin on rat testes exposed to $950 \mathrm{MHz}$ electromagnetic field. J. Biosc. Appl. Res., 1(3): 97-111.

Abdelhafez, H.M. (2008). Effect of Cabbage brassica Oleraceae (Var.capitata) seed extract and gamma rays on rat testis. M.Sc. Thesis, Faculty of Science, Al Azhar University.

Aitken, R.J.; Bennetts, L.E.; Sawyer, D.; Wiklendt, electromagnetic radiation on DNA integrity in the male germ line. Int. J. Androl.,_28(3): 171-179.

Akdag, M.Z.; Dasdag, S.; Canturk, F.; Karabulut, D.; Caner, Y. and Adalier, N. (2016). Does prolonged radiofrequency radiation emitted from $\mathrm{Wi}-\mathrm{Fi}$ devices induce DNA damage in various tissues of rats. J. Chem. Neuroanat., 7:15-19.

Bakhit, M.A. (2010). Modulation of radiation injury in pregnant rats by bone marrow transplantation. M.Sc. Thesis, Zoology Department, Faculty of Science, Al-Azhar University.

Bancroft, J.D. and Gamble, M. (2002). Theory and

Becker, E. (2004). Microalgae in human and animal nutrition. In: Handbook of Microalgae Culture. Biotechnology and Applied Phycology. Black well Science, Oxford, p. 13.

Belay, A.O. (2002). The potential application of Spirulina (Arthrospira) as a nutritional and therapeutic supplement in health management. Rev. J. Am. Nutraceut. Assoc., 5: 27-48.

Bock, R.K. (2008). Very high energy gamma rays from distant quasar: how transparent is the universe? Science, 320(5884): 1752-1754.

Dasdag, S.; Akdag, M.Z.; Kizil, G.; Kizil, M.; Cakir, D.U. and Yokus, D. (2012). Effect of $900 \mathrm{MHz}$ radio requency radiation on beta amyloid protein, protein carbonyl and malondialdehyde in the Brain. Electromag. Biol. Med., 31(1): 67-74.

Demir, A.; Tanidir, Y.; Karadag, M.A.; Atasoy, B.M.; Bozkurt, Z. and Cecen, K. (2015). Effects of testosterone treatment on recovery of rat spermatogenesis after irradiation. J. Pak. Med. Assoc., 65(3): 300-308.

Donnely, E.H.; Nemhauser, J.B. and Smith, J.M. (2010): Acute radiation syndrome: assessment and management. South Med. J., 103(6): 541-546. A.M. and King, B.V. (2005). Impact of radio frequency 
Drury, R. and Wallington, E. (1980). Carleton's unipolar pulsating magnetic field in mice. J. Korean Med. Histological Technique. $4^{\text {th }}$ ed. Oxford Univ. Press, New $\quad$ Sci., 12 (2): 128-134.

York.

Khuantrairong, T. and Traichaiyaporn, S. (2012).

Eid, F.; Abouzeid, M.; Hanaf, N. and El Dahshan, A. Enhancement of carotenoid and chlorophyll content of an (2013). Mobile phone radiation induced plasma protein edible freshwater alga (Kai: Cladophora sp.) by supplemenalterations and eye pathology in newly born mice. J.H. M., taryinorganic phosphate and investigation of its biomass 52: 572-592. production. Maejo. Int. J. Sci. Technol., 6(01): 1-11.

El-Depsi, S.M. (2016). Evolution of the role of Kumar, S. and Tiku, A.B. (2016).Immunomodulatory glibenclamid and Aphanizomenon flos-aquae extract on potential of acemannan (polysaccharide from Aloe vera) some organs of the induced diabetic rats. M.Sc. Thesis, against radiation induced mortality in Swiss albino mice. Faculty of Science, Al-Azhar University.

El-Desoky, E.; Bashandy, S.A.; Alhazza, I.M.; AlFood Agricul. Immunol., 27(1): 72-86.

Li, Y.J.; Han, Z.1.; Ge, L.; Zhou, C.J.; Zhao, Y.F.; Othman, Z.A.; Aboul-Soud, M.A. and Yusuf, K. (2013). Wang, D.H.; Ren, J.; Niu, X.X. and Liang, C.G. (2016). CImprovement of mercuric chloride-induced testis injuries phycocyanin protects against low fertility by inhibiting and sperm quality deteriorations by Spirulina platensis in reactive oxygen species in aging mice. Oncotarget, rats. PLOS One, available on doi: 10.1371/journal.pone.0059177Vol. available on: doi: 10.18632/oncotarget.8165.

Lijnen, P.; Prihadi, J.S.; Van-Pelt, J.F. and Fagard,

El-Sabagh, M.R.; Eldaim, M.A.A.; Mahboub, D.H. R.H. (2011). Modulation of reactive oxygen species and and Abdel-Daim, M. (2014). Effects of Spirulina platensis collagen synthesis by angiotensin II in cardiac fibroblasts. algae on growth performance, antioxidative status and The Open Hypertension J., 4: 1-17.

blood metabolites in fattening lambs. J. Agric. Sci., 6: 9298.

Liu, Y.; Cheng, Y.J.; Chen, C.K. and Yang, B.C. (2005). Coexposure of lead and lipopolysaccharide-induced

El-Salkh, B. (2009). Histological and histochemical liver injury in rats: involvement of nitric oxide-initiated studies on the effect of the alternating magnetic field on the oxidative stress and TNF alpha. Shock, 23(4): $360-364$. mice lung. Egypt. J. Biomed. Sci., 29: 351-366.

Luo, Q.; Cui, X.; Yan, J.; Yang, M.; Liu, J. and

El-Tantawy, W.H. (2015). Antioxidant effects of Jiang, Y. (2011). Antagonistic effects of Lycium barbarum Spirulina supplement against lead acetate-induced hepatic polysaccharides on the impaired reproductive system of injury in rats. Open Access Funded by Center for Food and male rats induced by local subchronic exposure to 60Co- $\gamma$ Biomolecules, National Taiwan University, available on: http://dx.doi.org/10.1016/j.jtcme.2015.02.001

radiation. Phytother. Res., 25: 694-701.

Massaad, C.A. (2011). Neuronal and vascular

Eriksen, N.T. (2008). Production of phycocyanin: a oxidative stress in Alzheimer's disease. Curr. pigment with applications in biology, biotechnology, foods Neuropharmacol., 9: 662-673.

and medicine. Appl. Microbiol. Biotech., 80:1-14.

Farag, M.R.; Alagawany, M.; Abd El-Hack, M.E. and Dhama, K. (2016): Nutritional and healthical aspects of with mercuric bromophenol blue. Biol. Bull., 104:57-67.

Spirulina (Arthrospira) for poultry, animals and human. Int. $\quad$ McVey, M.J.; Cooke, G.M.; Curran, I.H.; Chan, J. Pharmacol., 12: 36-51.

H.M. and Kubow, S. (2008). An investigation of the effects

Farrag, A.H. and Shalby, S.E.M. (2007). of methyl mercury in rats fed different dietary fats and Comparative histopathological and histochemical studies on proteins: testicular steroidogenic enzymes and serum IGR, lufenuron and profenofos insecticide albino rats. J. testosterone levels. Food Chem. Toxicol., 46: $270-279$.

Appl. Sci. Res., 3(5): 377-386.

Mohammed, M.M. (2010). The possible protective

Gershwin, M.E. and Belay, A. (2008). Spirulina in role of Foeniculum vulgare Mill. Against radiation-induced Human Nutrition and Health. CRC Press-Boca, USA. pp: certain biochemical changes in albino rats. M.Sc. Thesis, 45-51.

Guler, G.; Turkozer, Z.; Ozgur, E.; Tomruk, A. and Faculty of Science, Beni-Suif University.

Nah, W.H.; Koh, I.K.; Ahn, H.S.; Kim, M.J.; Kang, Seyhan, N. (2009): Protein oxidation under extremely low H.G.; Jun, J.H. and Gye, M.C. (2012). Effec of spirulina frequency electric field in guinea pigs. Effect of N-acetyl-L- maxima on spermatogenesis and steroidogenesis in cysteine treatment. Gen. Physiol. Biophys., 28: 47-55. streptozotocin-induced type 1 diabetic male rats. Food

Hanukoglu, I. (2006). Antioxidant protective chem., 134: 173-179.

mechanisms against reactive oxygen species (ROS) Nakamura, N., Hirai, Y. and Kodama, Y. (2012). generated by mitochondrial P450 systems in steroidogenic Gamma-ray and neutron dosimetry by EPR and AMS, using cells. Drug Metabolism Rev., 38: 171-196.

Ibrahim, R. and Ghoneim, M. (2014). Study of some Radiat. Prot. Dosimetry., 149(1) 79-83.

biochemical and molecular changes induced by radiation hormesis in testicular tissues of male rats. Egypt. Int. J. Adv. Res., 2 (7): 397-407.

Narayana, K.; Prashanthi, N.; Nayanatar, A.; Kumar, H.H.C. and Abhilash, K. (2005). Effects of methyl parathion (o,o-dimethyl o-4-nitropheny phosphorothioate)

Kang, H.; Lee, C.H.; Seo, J.W.; Sung, R.H., Chung, on rat sperm morphology and sperm count, but not fertility, Y.H.; Lee, S.K.; Suh, Y.H. and Chi, J.G. (1997). In-vivo are associated with decreased ascorbic acid level in the study on the harmful effect of the extremely low frequency testis. Mutat. Res., 588: 28-34. 
National Research Council (1996). Guide for the Care and Use of Laboratory Animals. $7^{\text {th }}$ ed. National Academy Press, Washington.

Odac, E.; Hanc, H.; Yulug, E.; Turedi, S.; Aliyazıcıglu, Y.; Kaya, H. and Colakoglu, S. (2016). effect of ascorbic acid supplementation on sperm quality, Effects of prenatal exposure to a $900 \mathrm{MHz}$ electromagnetic lipid peroxidation and testosterone levels of male Wistar field on 60 day-old rat testis and epididymal sperm quality. rats. Theriogenol., 63: 2063-2072.

Biotech. Histochem., 91(1): 9-19.

Uttara, B.; Singh, A.V.; Zamboni, P. and Mahajan,

Paget, E. and Barns, M. (1964). Interspecies dosage R.T. (2009). Oxidative stress and neurodegenerative conversion scheme in evaluation of results and quantitative diseases: a review of upstream and downstream antioxidant application in different species. Evaluation of Drug therapeutic options. Curr. Neuropharmacol., 7(1): 65-74.

Activities Pharmacometric, 1: 160-162.

Valle, S. (1986): Special stains in microwave oven. J.

Pears, A. (1977). Histochemistry Theoretical and Histotechnol., 9: 237-248. Applied. $3^{\text {rd }}$ ed. Churchill Livingstone, London, p. 1.

Venkatesan, S.; Pugazhendy, K.; Meenambal, M.;

Poli, G.; Biasi, F. and Leonarduzzi, G. (2008). 4- Sangeetha, D.; asantharaja, C.V.; Jayachandren, K. and hydroxynonenal protein adducts: a reliable biomarker of Prabakaran, S. (2012). Protective role of Spirulina on the lipid oxidation in liver diseases. Mol. Aspe. Med., 29: 67- variation of hematological parameter induced by herbicide 71.

Pugh, N. and Pasco, D.S. (2001). Characterization of J. Pharm. Biol. Arch., 3: 249-254.

human monocyte activation by a water soluble preparation of Aphanizomenon flos-aquae. Phytomed., 8: 445-453.

Sakr, S.A. and Okdah, Y.A. (2004): Histological and histochemical alteration induced in the testicular tissue of mice intoxicated with benomyle. J. Biol. Sci., 4(4): 498500 .

Sakr, S.A. and Shalaby, S.Y. (2011). Ginger extract protects metalaxyl-induced histomorphological and histochemical alterations in testes of albino mice. J. Appl. Pharm. Sci., 1(10): 36-42.

Salazar, M.; Chamorro, G.A.; Salazar, S. and Steele, C.E. (1996). Effect of Spirulina maxima consumption on reproduction and peri- and postnatal development in rats. Food Chem. Toxicol., 34: 353-359.

Samarth, R.M. and Samarth, M. (2009). Protection against radiation-induced testicular damage in Swiss albino mice by Mentha piperita (Linn.). Basic Clin. Pharmacol. Toxicol., 104: 329-34.

Schaap, A.; Rohrlack, T. and Bellouard, Y.(2012):Optical classification of algae species with glass lab on a chip. Lab. Chip., 12: 1527-1532. Scoglio, S.; Benedetti, Y.; Benvenuti, F. and 376.

Battistelli, S. (2014). Selective monoamine oxidase B inhibition byan Aphanizomenon flos-aquae extract and by its constitutive active principles phycocyanin and mycosporine-like amino acids. Phytomed., 21(7): 992-997.

Shanmugapriya, B.; Babu, S.S.; Hariharan, T.; Sivaneswaran, S. and Anusha, M.B. (2015): Dietary administration of Spirulina platensis as probiotics on growth performance and histopathology in broiler chicks. Int. J. Recent Scient. Res., 6: 2650-2653.

Shetty, G.; Zhou, W.; Weng, C.C.Y.; Shao, S.H. and Meistrich, M. L. (2016). Leydig cells contribute to the inhibition of spermatogonial differentiation after irradiation of the rat. Department of Experimental Radiation Oncology, University of Texas MD Anderson Cancer Center, USA. Online: doi: 10.1111/andr.12168. ISSN: 2047-2919.

Singh, S.; Kate, B.N. and Banerjee, U.C. (2005). Bioactive compounds from cyanobacteria and microalgae: an overview. Crit. Rev. Biotechnol., 25: 73-95.
Volesky, B. and Holan, Z.R. (1995). Biosorption of heavy metals. Biotechnol., 11: 235-250.

Wu, Z.; Shena, H.; Ondruschkab, B.; Zhanga, Y.; Wanga, W. and David, H. (2012). Removal of blue-green algae using the hybrid method of hydrodynamic cavitation and ozonation. 235(15): 152-158.

Yang, S.P.; Kuo, Y.L.; Lai, Y.S. and Chou, T.C. (2013): Mechanisms involved in the antiplatelet effect of Cphycocyanin. Br. J. Nutr., 95: 435-440.

Yang, Y.; Park, Y.; Cassada, D.A.; Snow, D.D.; Rogers, D.G. and Lee, J. (2011). In vitro and in vivo safety ssessment of edible blue-green algae, Nostoc commune var. Sphaeroides kutzing and Spirulina plantensis. Food Chem. Toxicol., 49(7):1560-1564.

Yokonishi, T. and Ogawa, T. (2016). Cryopreservation of testis tissues and in vitro spermatogenesis. Rev. Reprod. Med. Biol., 15(1): 21-28.

Yoshioka, T.; Kawada, K.; Shimada, T. and Mori, M. (1979). Lipid peroxidation in maternal and cord blood and aprotective mechanism against activated-oxygen toxicity in the blood. Am. J. of Obstetrics and Gynecol., 135(3): 372- 
